\title{
Clostridium clariflavum sp. nov. and Clostridium caenicola sp. nov., moderately thermophilic, cellulose-/cellobiose-digesting bacteria isolated from methanogenic sludge
}

Correspondence Hatsumi Shiratori siratori@brs.nihon-u.ac.jp

\author{
Hatsumi Shiratori, ${ }^{1}$ Kinuyo Sasaya, ${ }^{1}$ Hitomi Ohiwa, ${ }^{1}$ Hironori Ikeno, ${ }^{1}$ \\ Shohei Ayame, ${ }^{2}$ Naoaki Kataoka, ${ }^{2}$ Akiko Miya, ${ }^{2}$ Teruhiko Beppu ${ }^{1}$ \\ and Kenji Ueda ${ }^{1}$ \\ ${ }^{1}$ Life Science Research Center, College of Bioresource Sciences, Nihon University, 1866 Kameino, \\ Fujisawa 252-8510, Japan \\ ${ }^{2}$ Ebara Research Co., Ltd, 4-2-1, Honfujisawa, Fujisawa 251-8502, Japan
}

The Gram-positive bacterial genus Clostridium was first proposed by Prazmowski in 1880. To date, the names of over 190 species of this genus have been validly published (http://www.bacterio.cict.fr/c/clostridium.html). Most of the members are chemo-organotrophs that can utilize carbohydrates and/or proteinaceous compounds as energy sources. In the classic taxonomy, the organisms had only to meet four criteria to be classified as a member of Clostridium, i.e. endospore formation, obligately anaerobic growth, a Gram-positive cell wall and no ability to perform dissimilatory reduction of sulfate. The genus was thus highly divergent and did not form a monophyletic group. To clarify this phylogenetic incoherence, Collins et al.

Abbreviation: DMA, dimethylacetal.

The GenBank/EMBL/DDBJ accession numbers for the 16S rRNA gene sequences of strains $\mathrm{EBR}^{4} 5^{\top}$ and $\mathrm{EBR}^{\mathrm{N}} 56^{\top}$ are $\mathrm{AB} 186359$ and AB221372.
(1994) proposed reclassification of the genus Clostridium and related taxa into newly established phylogenetic groups based on the 16S rRNA gene sequences. Following this, Wiegel et al. (2006) proposed a new approach: that members of Clostridium cluster I, including the type strain, comprise the genus Clostridium sensu stricto and that those remaining outside this cluster are reclassified within different phylogenetic groups. According to this criterion, the members of cluster III, which includes industrially important cellulose digesters, should be distinguished from Clostridium sensu stricto, but appropriate reclassification has not yet been carried out due to insufficient information with regard to the phylogenetic and physiological properties of its constituents.

We study the application of an anaerobic thermophilic methanogenic bioreactor to the utilization of municipal solid wastes. Recently, we succeeded in isolating an 
effective cellulose-degrading strain of the genus Clostridium, strain EBR45 ${ }^{\mathrm{T}}$, which played a major role in the efficient operation of the bioreactor that digested artificial municipal waste containing homogenized photocopy paper (Shiratori et al., 2006). The result of $16 \mathrm{~S}$ rRNA gene sequence-based phylogenetic analysis indicated that strain $\mathrm{EBR} 45^{\mathrm{T}}$ and another isolate from the same sludge, strain EBR596 ${ }^{\mathrm{T}}$, were representatives of novel species within Clostridium cluster III. In this paper, we describe the taxonomic characterization of these isolates.

Unless noted otherwise, cultivation of strains $\mathrm{EBR} 45^{\mathrm{T}}$ and EBR596 $^{\mathrm{T}}$ was performed using $\mathrm{M}$ solution, which was prepared by mixing $980 \mathrm{ml}$ basal solution with $10 \mathrm{ml}$ each of vitamin solution and mineral solution. The basal solution had the following composition $\left(\mathrm{I}^{-1}\right.$; all chemicals from Kokusan unless indicated otherwise): $0.4 \mathrm{~g} \mathrm{KH}_{2} \mathrm{PO}_{4}$, $0.4 \mathrm{~g} \mathrm{~K}_{2} \mathrm{HPO}_{4} .3 \mathrm{H}_{2} \mathrm{O}, 1.0 \mathrm{~g} \mathrm{NH}_{4} \mathrm{Cl}, 0.1 \mathrm{~g} \mathrm{MgCl}_{2} .6 \mathrm{H}_{2} \mathrm{O}$, 2.0 g yeast extract (Difco), $6.0 \mathrm{~g} \mathrm{NaHCO}_{3}, 0.5 \mathrm{~g}$ cysteine hydrochloride monohydrate, $0.25 \mathrm{~g} \quad \mathrm{Na}_{2} \mathrm{~S} .9 \mathrm{H}_{2} \mathrm{O}$ (Yoneyama) and $0.001 \mathrm{~g}$ resazurin. The vitamin solution had the following composition $\left(\mathrm{l}^{-1}\right): 2 \mathrm{mg}$ biotin, $2 \mathrm{mg}$ folic acid, $10 \mathrm{mg}$ pyridoxine hydrochloride, $5 \mathrm{mg}$ thiamine hydrochloride, $5 \mathrm{mg}$ riboflavin, $5 \mathrm{mg}$ nicotinic acid, $5 \mathrm{mg}$ DL-calcium pantothenate, $0.1 \mathrm{mg}$ vitamin $\mathrm{B}_{12}, 5 \mathrm{mg} p$ aminobenzoic acid and $5 \mathrm{mg}$ lipoic acid. The mineral solution had the following composition $\left(1^{-1}\right)$ : $4.5 \mathrm{~g}$ nitrilotriacetic acid, $0.4 \mathrm{~g} \quad \mathrm{FeCl}_{2} .4 \mathrm{H}_{2} \mathrm{O}, \quad 0.12 \mathrm{~g}$ $\mathrm{CoCl}_{2} \cdot 6 \mathrm{H}_{2} \mathrm{O}, \quad 0.01 \mathrm{~g} \quad \mathrm{AlK}\left(\mathrm{SO}_{4}\right)_{2}, \quad 1.0 \mathrm{~g} \quad \mathrm{NaCl}, \quad 0.02 \mathrm{~g}$ $\mathrm{CaCl}_{2}, 0.01 \mathrm{~g} \mathrm{Na}_{2} \mathrm{MoO}_{4} .2 \mathrm{H}_{2} \mathrm{O}, 0.1 \mathrm{~g} \mathrm{MnCl}_{2} .4 \mathrm{H}_{2} \mathrm{O}, 0.1 \mathrm{~g}$ $\mathrm{ZnCl}_{2}, 0.01 \mathrm{~g} \mathrm{H}_{3} \mathrm{BO}_{3}, 0.01 \mathrm{~g} \mathrm{CuSO}_{4} \cdot 5 \mathrm{H}_{2} \mathrm{O}$ and $0.02 \mathrm{~g}$ $\mathrm{NiCl}_{2}$. M solution was supplied with various cellulosic substrates to prepare each culture medium. Mc medium contained $0.5 \%(\mathrm{w} / \mathrm{v})$ cellobiose in $\mathrm{M}$ solution. Mpc medium contained $1.0 \%(\mathrm{w} / \mathrm{v})$ cellulose powder (type D; Advantec) in $\mathrm{M}$ solution. The bacteria were cultivated routinely in a screw-capped test tube under an oxygen-free nitrogen atmosphere without shaking at $55^{\circ} \mathrm{C}$ (for strain EBR $45^{\mathrm{T}}$ ) or $60{ }^{\circ} \mathrm{C}$ (for strain EBR596 $6^{\mathrm{T}}$ ) and maintained as a glycerol suspension $(10 \%, \mathrm{w} / \mathrm{v})$ at $-80{ }^{\circ} \mathrm{C}$. The reference strains Clostridium thermocellum DSM $1237^{\mathrm{T}}$, C. stercorarium subsp. stercorarium DSM $8532^{\mathrm{T}}$ and C. straminisolvens JCM $21531^{\mathrm{T}}$ were obtained from the DSMZ or JCM and cultured in Mc medium for analysis of cellular fatty acid composition.

Cell morphology was observed under a Zeiss Axioskop 2 optical microscope (Carl Zeiss Microimaging) and a JEM1200EX electron microscope (JEOL). For transmission electron microscopy, cells were fixed with $2.0 \%(\mathrm{v} / \mathrm{v})$ glutaraldehyde and $2.0 \%(\mathrm{v} / \mathrm{v})$ osmium tetroxide. The samples were embedded in Epoxy resin (Epon 812) and ultrathin sections of samples were prepared with an LKB8800 ultramicrotome. The samples were stained with $2.0 \%$ uranyl acetate and lead citrate. After vapour deposition treatment with carbon, the samples were observed.

The following physiological and biochemical characteristics were studied using the methods described by Holdeman et al. (1977): Gram-staining, motility, aesculin hydrolysis, nitrate reduction, sulfate reduction, indole production, casein digestion, gelatin liquefaction and activities of lecithinase, lipase and catalase. The potential for degradation of cellulose was tested using $\mathrm{M}$ solution supplemented with $1.0 \%(\mathrm{w} / \mathrm{v})$ each of filter paper (filter paper no. 1; Whatman), powdered cellulose (type D; Advantec), microcrystalline cellulose (Serva), photocopy paper (NBS Ricoh), newspaper and CM-cellulose (Wako). The temperature range for growth $(30,37,40,50,55,60,65$ and $70{ }^{\circ} \mathrm{C}$ ) was determined in $\mathrm{Mc}$ medium. The $\mathrm{pH}$ range ( $\mathrm{pH} 5.0-9.0$ at intervals of 0.5 or $1.0 \mathrm{pH}$ unit) for growth was determined in Mc medium adjusted by addition of $1 \mathrm{M} \mathrm{HCl}$ or $\mathrm{NaOH}$. Tolerance of salinity was tested in $\mathrm{Mc}$ medium supplemented with $\mathrm{NaCl}$ at $0-1 \% \mathrm{NaCl}$ (at intervals of $0.1 \%)$ and 2,3 and $5 \% \mathrm{NaCl}(\mathrm{w} / \mathrm{v})$. The potential for colony formation and oxygen tolerance at various oxygen concentrations $(0,1,2,4$ and $6 \%)$ were studied using $\mathrm{Mc}$ and $\mathrm{Mpc}$ solid medium (each broth medium solidified with $1.5 \%$ agar in a Petri dish) in an Anoxomat Mark II system (Mart Microbiology). Substrate utilization was studied in PY medium (Holdeman et al., 1977) and M solution supplemented with various carbohydrates $(1.0 \%, \mathrm{w} / \mathrm{v})$. Growth was judged by the increase of optical density or decrease of the culture broth $\mathrm{pH}$ after 5-7 days cultivation. Production of organic acids and gases $\left(\mathrm{H}_{2}\right.$ and $\left.\mathrm{CO}_{2}\right)$ was analysed by HPLC with an electric conductivity monitor (Shimadzu) and gas chromatography (model GC323; GL Science), respectively.

As partially described in a previous report (Shiratori et al., 2006), cells of strains EBR45 ${ }^{\mathrm{T}}$ and EBR596 ${ }^{\mathrm{T}}$ were thermophilic, spore-forming, flagellated rods (Fig. 1a, b). Phenotypic characteristics of the two isolates are summarized in Table 1 and in the species descriptions. Colonies of strain $\mathrm{EBR} 45^{\mathrm{T}}$ on Mc and Mpc solid medium were round, convex, about 1-2 $\mathrm{mm}$ in diameter, bright yellow in colour and had a slightly undulating margin. Colonies of strain EBR596 $6^{\mathrm{T}}$ on Mc solid medium were similar to strain EBR $45^{\mathrm{T}}$ in form and size but had a glossy white colour. Although the Gram-staining reaction of both isolates was negative or variable, the cell-wall ultrastructure resembled that of Gram-positive bacteria (Fig. 1c, d). Both strains retained clear S-layer structures at the outermost surface but they exhibited highly diverged cell-wall structures (longitudinal sections; insets in Fig. 1c, d). The salinity ranges $\left(\mathrm{NaCl}\right.$ concentration) for growth of strains $\mathrm{EBR} 45^{\mathrm{T}}$ and EBR596 ${ }^{\mathrm{T}}$ were $0-0.7 \%(\mathrm{w} / \mathrm{v})$ (optimum $0.4 \%$, no growth $\geqslant 2.0 \%$ ) and $0-1.5 \%$ (optimum $1.0 \%$ ), respectively. Both strains were anaerobic, as demonstrated by their inability to grow under aerobic conditions (no growth at $\mathrm{O}_{2}$ concentrations of $\geqslant 4 \%$ for $\mathrm{EBR} 45^{\mathrm{T}}$ and $\geqslant 2 \%$ for EBR596 $\left.{ }^{\mathrm{T}}\right)$. Strain EBR45 ${ }^{\mathrm{T}}$ digested various cellulose substrates (purified cellulose, papers and CM-cellulose) and accumulated an orange-yellow pigment on the surface of cellulose materials, while strain EBR596 ${ }^{\mathrm{T}}$ was non-cellulolytic. Strain EBR45 ${ }^{\mathrm{T}}$ did not utilize amygdalin, arabinose, glucose, maltose, mannitol, salicin or starch (each supplied 


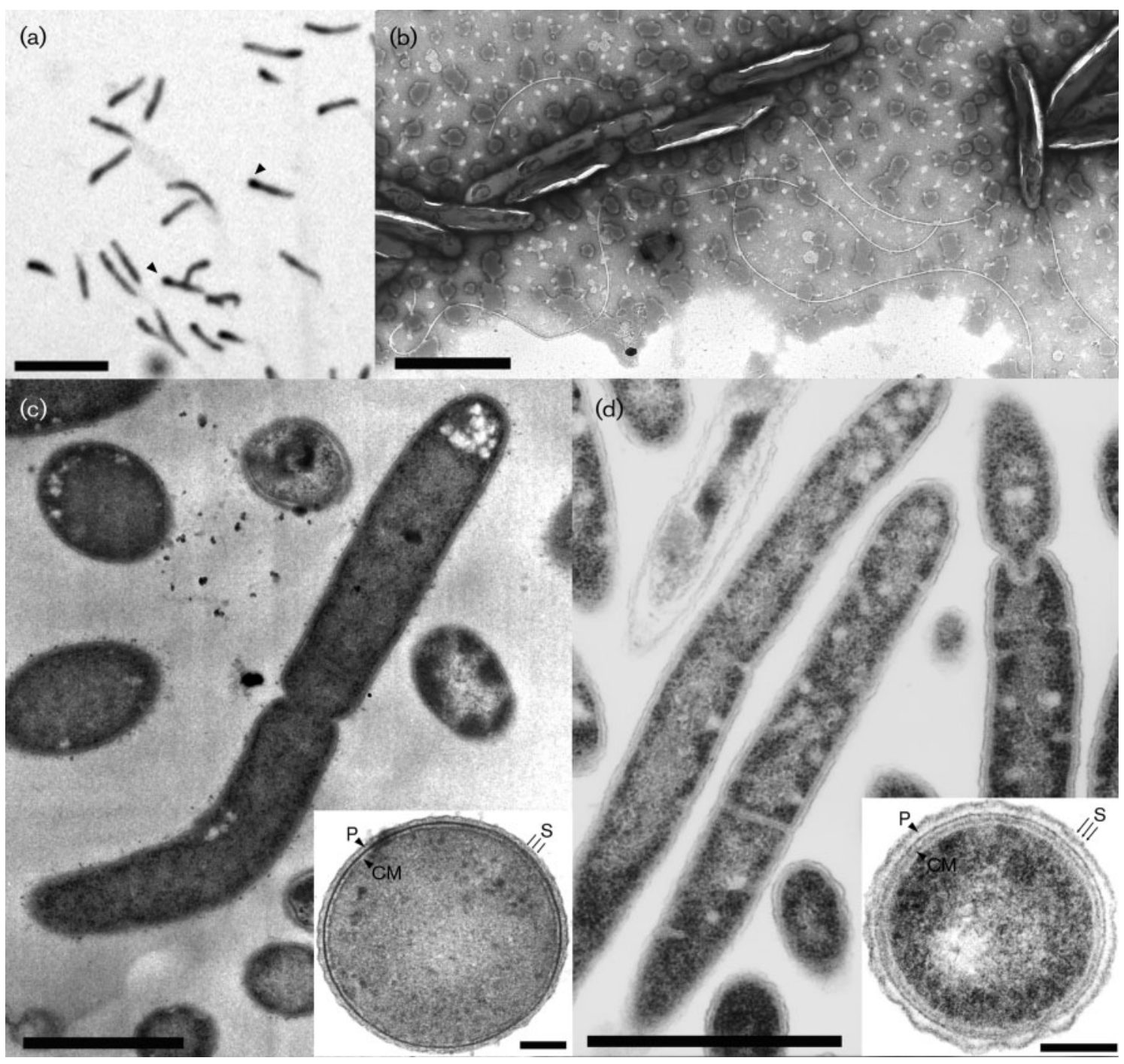

Fig. 1. Micrographs of strains EBR45 ${ }^{\top}$ and $E B R 596^{\top}$. (a) Optical micrograph of cells of strain EBR596 ${ }^{\top}$ grown in a cellobioseutilizing liquid culture. Arrows indicate spores within vegetative cells. Bar, $5 \mu \mathrm{m}$. (b) Electron micrograph of negatively stained cells of strain EBR596 ${ }^{\top}$. Bar, $1 \mu \mathrm{m}$. Optical micrographs of strain EBR45 ${ }^{\top}$ have been published previously (Shiratori et al., 2006). (c, d) Electron micrographs of cross sections and longitudinal sections (inset) of strains EBR45 ${ }^{\top}$ (c) and EBR596 ${ }^{\top}$ (d). $\mathrm{CM}$, Cytoplasmic membrane; P, peptidoglycan layer; S, S-layer. Bars, $1 \mu \mathrm{m}$ (c, d) and $0.1 \mu \mathrm{m}$ (insets).

at $1.0 \%)$ as carbon and energy sources, while strain EBR596 ${ }^{\mathrm{T}}$ utilized all of them. These features imply that these strains played different roles in the biomass degradation in the original methanogenic bioreactor.

Neither strain utilized any of the following carbohydrates: adonitol, dulcitol, erythritol, fructose, galactose, glycerol, glycogen, inositol, inulin, lactose, mannose, melibiose, melezitose, raffinose, rhamnose, ribose, sorbitol, sorbose, sucrose, trehalose, xylitol and xylose. The main fermentation products of the two strains in a cellobiose-utilizing culture were $\mathrm{H}_{2}, \mathrm{CO}_{2}$, lactate, acetate and ethanol. Strain $\mathrm{EBR} 45^{\mathrm{T}}$ also produced a detectable amount of formate. Both strains tested negative for the following biochemical properties: nitrate and sulfate reduction, indole produc- tion, casein digestion, gelatin liquefaction and lecithinase, lipase and catalase activities.

DNA was extracted by using phenol/chloroform extraction followed by polyethylene glycol precipitation, based on the method described by Marmur (1961) with some modification. The DNA G $+\mathrm{C}$ contents of strains $\mathrm{EBR} 45^{\mathrm{T}}$ and ${\text { EBR5 } 56{ }^{\mathrm{T}}}$ determined by an HPLC method (Mesbah \& Whitman, 1989) were 36.9 and $51.1 \mathrm{~mol} \%$, respectively (mean of three measurements). The 16S rRNA gene sequences were amplified by PCR with a bacterial domain-specific primer set, 27F/1492R (Wang et al., 2007). PCR was performed on a T1 Thermocycler (Biometra) with Ex Taq polymerase (Takara Bio). The PCR protocol included an initial denaturation period of 
Table 1. Differential phenotypic characteristics of strains EBR $45^{\top}$ and $E B R 596^{\top}$ and thermophilic members of cluster III in the low$\mathrm{G}+\mathrm{C}$-content Gram-positive bacteria

Taxa: 1, Clostridium clariflavum sp. nov. EBR45 ${ }^{\mathrm{T}}$; 2, Clostridium caenicola sp. nov. EBR596 ${ }^{\mathrm{T}}$; 3, C. thermocellum (data from McBee, 1954; Ng et al., 1977; Wiegel, 1980); 4, C. straminisolvens $\mathrm{CSK}^{\mathrm{T}}$ (unless indicated, data from Kato et al., 2004); 5, C. stercorarium subsp. stercorarium (Madden, 1983); 6, C. stercorarium subsp. leptospartum (Toda et al., 1988); 7, C. stercorarium subsp. thermolacticum (Le Ruyet et al., 1985). All taxa are positive for cellobiose utilization and aesculin hydrolysis. +, Positive; - , negative; w, weak; ND, data not available.

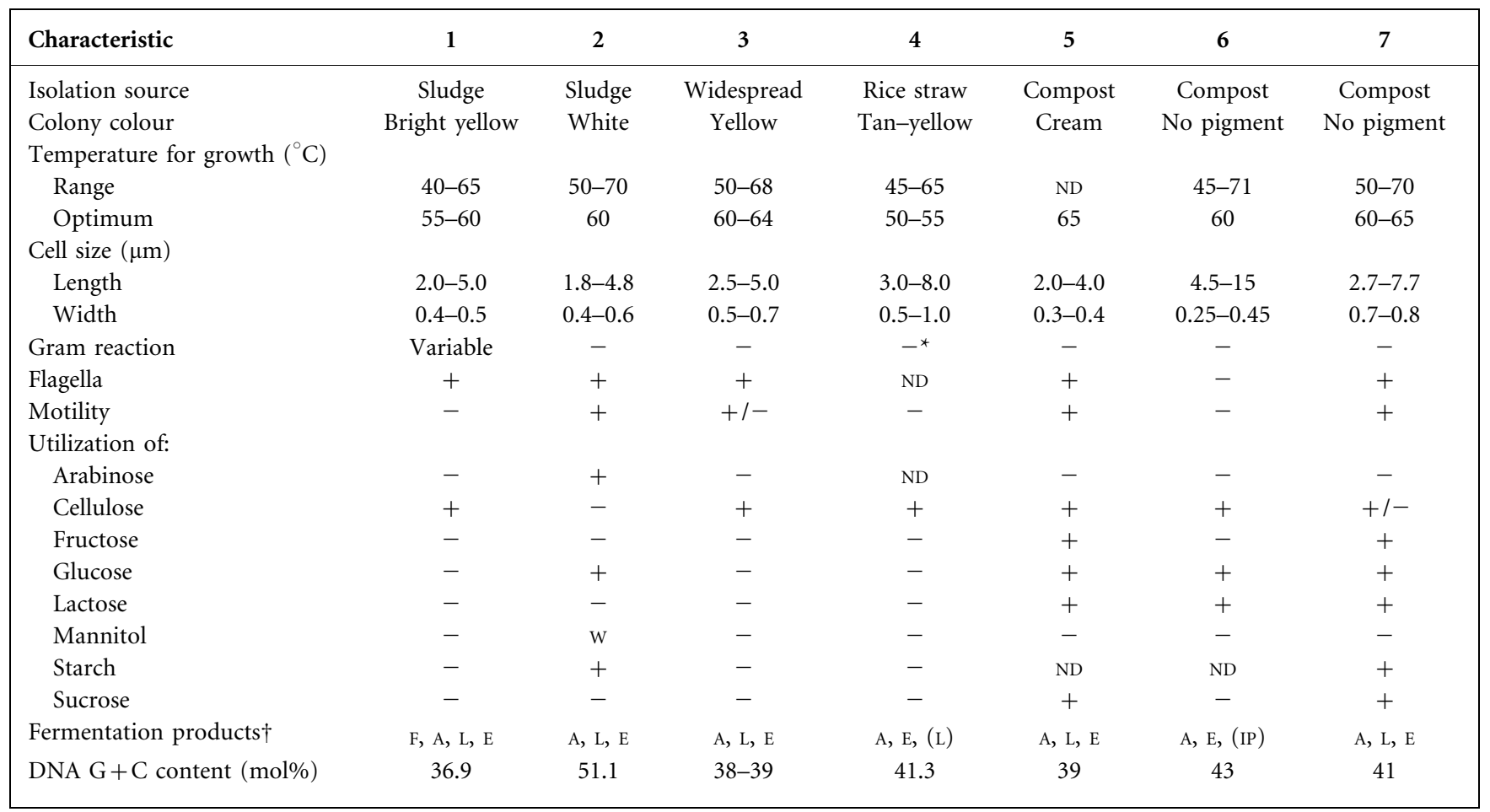

${ }^{\star}$ Data from this study.

$\dagger F$, Formate; A, acetate; L, lactate; E, ethanol; IP, isopentanol. Products found as traces are given in parentheses.

$94{ }^{\circ} \mathrm{C}$ for $4 \mathrm{~min}, 30$ cycles of $94{ }^{\circ} \mathrm{C}$ for $1 \mathrm{~min}, 55{ }^{\circ} \mathrm{C}$ for $1 \mathrm{~min}$ and $72{ }^{\circ} \mathrm{C}$ for $1 \mathrm{~min}$, an extension period of $72{ }^{\circ} \mathrm{C}$ for $3 \mathrm{~min}$, and incubation at $4{ }^{\circ} \mathrm{C}$ until further processing. The nearly complete $16 \mathrm{~S}$ rRNA gene sequences of strains $\mathrm{EBR}_{4} 5^{\mathrm{T}}$ (1560 bp) and EBR596 ${ }^{\mathrm{T}}$ (1435 bp) were determined directly by using a BigDye terminator v3.1 cycle sequencing kit on an ABI 3130 Genetic Analyzer (Applied Biosystems). Analysis of the sequences was performed with the software package MEGA version 3.1 (Kumar et al., 2004) after multiple alignment of sequences by CLUSTAL W (Thompson et al., 1994) and SEAVIEW (Galtier et al., 1996). Phylogenetic trees were constructed using the neighbour-joining (Saitou \& Nei, 1987) and maximumparsimony (Fitch, 1971) methods. A bootstrap analysis (1000 replications) was carried out to evaluate the topology of the resulting tree (Felsenstein, 1985). The evolutionary distance matrix for the neighbour-joining method was generated according to the model of Jukes \& Cantor (1969).

The neighbour-joining tree of 16S rRNA gene sequences, which was also supported by the maximum-parsimony method, showed that the two isolates were members of the thermophilic group of cluster III (Collins et al., 1994; Wiegel et al., 2006) within the low-G + C-content Grampositive bacteria (Fig. 2). Sequence similarity calculations using the BLAST program (http://www.ncbi.nlm.nih.gov/ BLAST/) indicated that strain EBR $45^{\mathrm{T}}$ showed highest similarities to C. straminisolvens DSM $16021^{\mathrm{T}}$ (sequence identity $94.6 \%$ ) and C. thermocellum DSM $1237^{\mathrm{T}}$ (93.4\%). The closest relatives of strain EBR $596^{\mathrm{T}}$ were C. stercorarium subsp. stercorarium DSM 8532 ${ }^{\mathrm{T}}$, C. stercorarium subsp. leptospartum DSM $9219^{\mathrm{T}}$ and C. stercorarium subsp. thermolacticum DSM $2910^{\mathrm{T}}$ (sequence identities 95.0$95.9 \%$ ). These identity scores are low enough, according to Stackebrandt \& Goebel (1994), to justify the description of strains EBR $45^{\mathrm{T}}$ and EBR596 ${ }^{\mathrm{T}}$ as representatives of novel species of cluster III. These results support the view that strains EBR $45^{\mathrm{T}}$ and EBR596 ${ }^{\mathrm{T}}$ can be discriminated from their closest relatives at the species level (Wayne et al., 1987).

Fatty acid methyl esters were extracted and analysed according to the standard protocol of the Sherlock Microbial Identification System (version 5.0; MIDI). The cellular fatty acid profiles of strains EBR $45^{\mathrm{T}}$ and EBR596 ${ }^{\mathrm{T}}$ and related type strains belonging to the cluster III are 


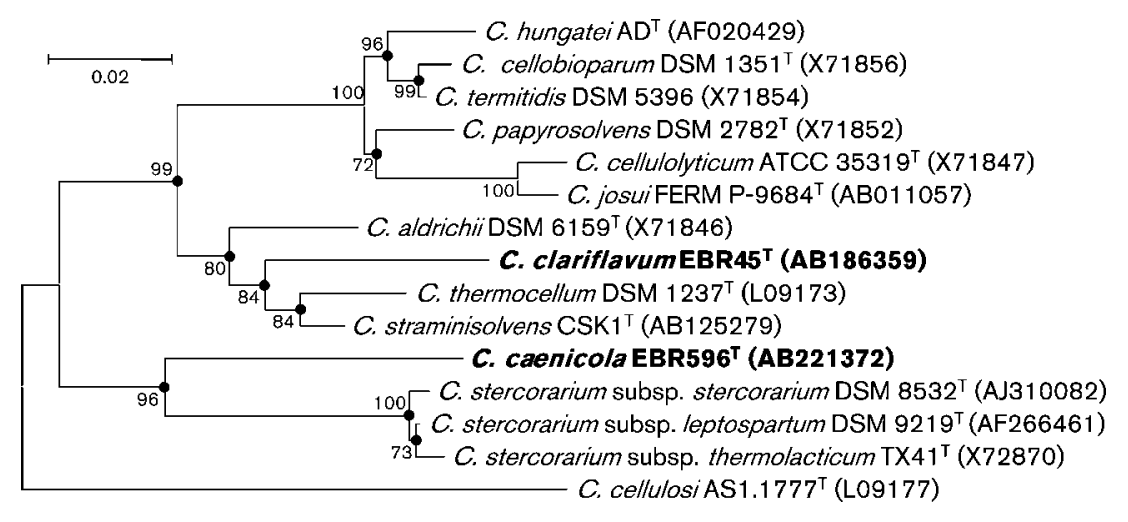

Fig. 2. Neighbour-joining phylogenetic tree based on 16S rRNA gene sequences showing the relationship of strains EBR45 ${ }^{\top}$ and EBR596 ${ }^{\top}$ among cluster III within the low$\mathrm{G}+\mathrm{C}$-content Gram-positive bacteria. Numbers at nodes represent bootstrap values (expressed as percentages of 1000 resampled datasets) obtained in the neighbour-joining analysis. Solid circles indicate branching supported by the maximum-parsimony method. The sequence of Clostridium cellulosi AS1.1777 ${ }^{\top}$ was used as an outgroup. Bar, 0.02 substitutions per nucleotide position. shown in Table 2. The major fatty acids of strain EBR $45^{\mathrm{T}}$ were 16:0,16:0 iso and 16:0 dimethylacetal (DMA), which accounted for $60.6 \%$ of the total fatty acids. The major fatty acids of strain EBR596 ${ }^{\mathrm{T}}$ were $15: 0$ iso, $16: 0$ iso, 15:0 anteiso and 17:0 anteiso, which accounted for $60.5 \%$ of the total fatty acids. This result was consistent with the fatty acid pattern of Gram-positive, sporeforming, low-G +C-content and thermophilic bacteria, which usually contain long-chain $\left(\mathrm{C}_{16}-\mathrm{C}_{18}\right)$ saturated forms as the predominant fatty acids (Chan et al., 1971; Kaneda, 1991). The fatty acid profile of strain EBR $45^{\mathrm{T}}$ differed from that of C. straminisolvens JCM $21531^{\mathrm{T}}$ and $C$. thermocellum DSM $1237^{\mathrm{T}}$ in the presence of $15: 0(0.62 \%)$, $18: 1 \omega 9 c(0.57 \%)$ and summed feature $13(15: 0$ anteiso DMA and/or 14:0 2-OH; 0.20\%). Strain EBR596 ${ }^{\mathrm{T}}$ could be differentiated from C. stercorarium subsp. stercorarium DSM $8532^{\mathrm{T}}$ in the presence of branched forms 13:0 iso $(1.36 \%), \quad 16: 0 \quad 3-\mathrm{OH} \quad(0.40 \%), \quad 17: 0$ anteiso $3-\mathrm{OH}$ $(1.31 \%)$ and $19: 0 \Delta 9,10$ and $\Delta 11,12$ DMA $(1.54 \%$ in total).

The members of Clostridium cluster III (Collins et al., 1994), which currently consists of 12 cellulolytic species/ subspecies, are phenotypically heterogeneous (e.g. this cluster includes both mesophiles and thermophiles). In addition, they exhibit a broad range of DNA G $+\mathrm{C}$ content (28-43 mol\%). Despite this heterogeneity, it is known that cluster III is clearly distinguished from not only Clostridium cluster I (sensu stricto) but also clusters II and IV in terms of 16S rRNA gene phylogeny (Collins et al., 1994; Wiegel et al., 2006). The result of this phylogenetic analysis clearly shows that strains EBR $45^{\mathrm{T}}$ and $\mathrm{EBR} 596^{\mathrm{T}}$ fall into the thermophilic group of cluster III (Fig. 2). This indicates that these two novel isolates are closely related to the members of the cluster III, although the significant phylogenetic distances from the closest relatives (Fig. 2) imply that the two isolates are affiliated with taxa that are distinct from others in the cluster. In addition, strains EBR45 ${ }^{\mathrm{T}}$ and $\mathrm{EBR} 596^{\mathrm{T}}$ could be distinguished from their relatives as follows: strain $\mathrm{EBR} 45^{\mathrm{T}}$ differed from its phylogenetic relatives, C. thermocellum and C. straminisolvens, in its temperature range for growth and DNA
$\mathrm{G}+\mathrm{C}$ content; strain $\mathrm{EBR} 45^{\mathrm{T}}$ produced formate as a fermentation product, whereas the two related species did not; strain EBR $596^{\mathrm{T}}$ differed from its close relatives, the subspecies of C. stercorarium, in its substrate-utilization patterns and DNA G+C content. Strain EBR596 ${ }^{\mathrm{T}}$ exhibited the highest DNA $\mathrm{G}+\mathrm{C}$ content within cluster III. Fatty acid content profiling also clearly differentiated both the novel isolates from their relatives.

Based on the above evidence, strains EBR $45^{\mathrm{T}}$ and EBR596 ${ }^{\mathrm{T}}$ are proposed to be representatives of two novel species of Clostridium cluster III in the low-G + C-content Grampositive bacteria, for which the names Clostridium clariflavum sp. nov. and Clostridium caenicola sp. nov. are proposed.

\section{Description of Clostridium clariflavum sp. nov.}

Clostridium clariflavum (cla.ri.fla'vum. L. adj. clarus clear, bright, shining, brilliant; L. neut. adj. flavum yellow; N.L. neut. adj. clariflavum bright yellow, the colour of the colonies or pigment).

Moderately anaerobic, thermophilic and chemo-organotrophic. Cells are straight or slightly curved rods (0.4$0.5 \times 2.0-5.0 \mu \mathrm{m})$. Gram-type positive but Gram-staining reaction is variable. Non-motile, although retarded peritrichous flagella are present. Spores are oval and subterminal. On solid agar containing cellulose or cellobiose as a carbon source, it forms bright yellow, round colonies (1$2 \mathrm{~mm}$ in diameter). Temperature range for growth is $45-$ $65{ }^{\circ} \mathrm{C}$ (optimum $55-60{ }^{\circ} \mathrm{C}$ ). $\mathrm{pH}$ range for growth is $\mathrm{pH}$ 6.0-8.0 (optimum $\mathrm{pH} 7.5$ ). The salinity $(\mathrm{NaCl})$ range for growth is $0-0.7 \%(\mathrm{w} / \mathrm{v})$ (optimum $0.4 \% \mathrm{w} / \mathrm{v}$ ). Colony formation is observed under anaerobic conditions $\left(\mathrm{O}_{2}<4 \%\right)$. Cellulose and cellobiose are utilized as sole carbon and energy sources; fermentation products are hydrogen, carbon dioxide, acetate, lactate, ethanol and a small amount of formate. The following compounds are not utilized: glucose, adonitol, amygdalin, arabinose, dulcitol, erythritol, fructose, galactose, glycerol, glycogen, inositol, inulin, lactose, maltose, mannitol, mannose, melibiose, melezitose, raffinose, rhamnose, ribose, salicin, 
Table 2. Cellular fatty acid composition (\%) of strain EBR45 ${ }^{\top}$, strain EBR596 ${ }^{\top}$ and type strains of thermophilic species of cluster III within the low-G +C-content Gram-positive bacteria

Strains: 1, C. clariflavum sp. nov. EBR45 ${ }^{\mathrm{T}}$; 2 , C. caenicola sp. nov. EBR $596^{\mathrm{T}}$; 3, C. thermocellum DSM $1237^{\mathrm{T}} ; 4$, C. straminisolvens JCM $21531^{\mathrm{T}} ; 5$, C. stercorarium subsp. stercorarium DSM $8532^{\mathrm{T}}$. All data were obtained in this study. Major fatty acids are shown in bold.

\begin{tabular}{|c|c|c|c|c|c|}
\hline Fatty acid & 1 & 2 & 3 & 4 & 5 \\
\hline $13: 0$ iso & - & 1.36 & - & - & - \\
\hline $13: 0$ anteiso & - & 0.26 & - & - & - \\
\hline $13: 0$ iso $3-\mathrm{OH}$ & 1.37 & 0.08 & - & 0.33 & - \\
\hline $14: 0$ & 3.35 & 1.50 & - & 0.66 & 2.13 \\
\hline $14: 0$ iso & 0.94 & 1.99 & - & 0.36 & - \\
\hline 14:0 DMA & 3.22 & 0.09 & 0.51 & 0.74 & 1.03 \\
\hline $15: 0$ & 0.62 & - & - & - & - \\
\hline $15: 0$ iso & 1.67 & 18.85 & - & 0.77 & 1.73 \\
\hline $15: 0$ anteiso & - & 9.51 & - & 0.23 & 0.41 \\
\hline $15: 0$ iso DMA & 1.74 & 0.58 & 0.41 & 0.71 & 0.79 \\
\hline $16: 0$ & 20.43 & 5.92 & 16.59 & 22.87 & 52.21 \\
\hline $16: 03-\mathrm{OH}$ & - & 0.40 & - & - & - \\
\hline $16: 0$ iso & 23.70 & 22.97 & 11.80 & 28.31 & 1.97 \\
\hline 16:0 DMA & 16.47 & 0.29 & 20.39 & 13.13 & 19.75 \\
\hline $16: 1$ & - & - & - & - & - \\
\hline $16: 1 \omega 7 c$ & - & 1.18 & - & - & 5.25 \\
\hline 16:0 aldehyde & 4.83 & 0.06 & 5.27 & 4.30 & - \\
\hline $17: 0$ iso & 5.42 & 8.18 & 4.79 & 6.43 & 4.15 \\
\hline $17: 0$ anteiso & 1.22 & 9.18 & 0.98 & 2.65 & 3.04 \\
\hline $17: 0$ anteiso $3-\mathrm{OH}$ & - & 1.31 & - & - & - \\
\hline $17: 0$ anteiso DMA & - & 0.21 & 0.51 & 0.58 & 0.87 \\
\hline $18: 0$ & 0.73 & 0.24 & 5.39 & 1.38 & 2.81 \\
\hline $18: 0$ iso & 0.85 & 0.19 & 14.59 & 3.77 & - \\
\hline 18:0 DMA & 0.63 & - & 1.17 & 0.48 & - \\
\hline 18:0 aldehyde & - & - & - & 0.47 & - \\
\hline $18: 1$ & - & - & - & - & - \\
\hline $18: 1 \omega 9 c$ & 0.57 & 0.67 & - & - & 0.21 \\
\hline $19: 0 \Delta 9,10$ DMA & - & 1.32 & - & - & - \\
\hline $19: 0 \Delta 11,12$ DMA & - & 0.22 & - & - & - \\
\hline $20: 0$ & - & - & - & - & 1.73 \\
\hline Unknown 16.107 & 7.87 & 0.34 & 15.71 & 10.41 & 0.28 \\
\hline Unknown 17.103 & 1.84 & 0.15 & 1.87 & 0.80 & 0.50 \\
\hline Summed feature $1^{\star}$ & 1.70 & 0.30 & - & 0.21 & 0.35 \\
\hline Summed feature $3^{\star}$ & - & 4.69 & - & 0.22 & 0.22 \\
\hline Summed feature $13^{\star}$ & 0.20 & 0.51 & - & - & 0.22 \\
\hline
\end{tabular}

${ }^{\star}$ Summed feature 1 contained one or more of $13: 1,14: 0$ aldehyde and 11:12-OH; summed feature 3 contained 15:0 iso aldehyde and/ or an unknown fatty acid; summed feature 13 contained 15:0 anteiso DMA and/or 14:0 2-OH.

sorbitol, sorbose, sucrose, trehalose, xylitol and xylose. Hydrolysis of aesculin is positive, while hydrolysis of starch, casein or gelatin is negative. Negative for nitrate and sulfate reduction, indole production, lecithinase, lipase and catalase. The major cellular fatty acids are 16:0,16:0 iso and 16:0 DMA. The genomic $\mathrm{G}+\mathrm{C}$ content of the type strain is $36.9 \mathrm{~mol} \%$.
The type strain is $\mathrm{EBR}^{\mathrm{T}} 5^{\mathrm{T}}\left(=\mathrm{DSM} 19732^{\mathrm{T}}=\mathrm{NBRC}\right.$ $\left.101661^{\mathrm{T}}\right)$.

\section{Description of Clostridium caenicola sp. nov.}

Clostridium caenicola (cae.ni.co'la. L. n. caenum mud, sludge; L. suff. - cola dweller; N.L. n. caenicola sludge dweller).

Obligately anaerobic, thermophilic and chemo-organotrophic. Cells are motile, lophotrichously flagellated (a few flagella at a polar attachment point) and straight or slightly curved rods $(0.4-0.6 \times 1.8-4.8 \mu \mathrm{m})$. Gram-staining reaction is negative but shows Gram-positive cell-wall structure. Spores are oval and subterminal. Colonies are glossy white in colour on solid agar containing cellobiose as a carbon source. Temperature range for growth is $50-70{ }^{\circ} \mathrm{C}$ (optimum $60{ }^{\circ} \mathrm{C}$ ). $\mathrm{pH}$ range for growth is $\mathrm{pH} 6.0-8.0$ (optimum $\mathrm{pH}$ 6.5). The salinity $(\mathrm{NaCl})$ range for growth is $0-1.5 \%(\mathrm{w} / \mathrm{v})($ optimum $1.0 \% \mathrm{w} / \mathrm{v})$. Colony formation is observed under anaerobic conditions $\left(\mathrm{O}_{2}<2 \%\right)$. Cellobiose, amygdalin, arabinose, glucose, maltose, mannitol, salicin and starch are utilized as carbon and energy sources. The following compounds are not utilized: cellulose, adonitol, dulcitol, erythritol, fructose, galactose, glycerol, glycogen, inositol, inulin, lactose, mannose, melibiose, melezitose, raffinose, rhamnose, ribose, sorbitol, sorbose, sucrose, trehalose, xylitol and xylose. Fermentation products are hydrogen, carbon dioxide, acetate, lactate and ethanol. Hydrolysis of aesculin is positive, while hydrolysis of casein and gelatin is negative. Negative for nitrate and sulfate reduction, indole production, lecithinase, lipase and catalase. The major cellular fatty acids are 15:0 iso, 16:0 iso, 15:0 anteiso and 17:0 anteiso. The genomic $\mathrm{G}+\mathrm{C}$ content of the type strain is $51.1 \mathrm{~mol} \%$.

The type strain is EBR596 ${ }^{\mathrm{T}}\left(=\mathrm{DSM} 19027^{\mathrm{T}}=\mathrm{NBRC}\right.$ $\left.102590^{\mathrm{T}}\right)$.

\section{Acknowledgements}

We thank Professor Fred Rainey and anonymous reviewers for helpful advice, Dr Dalal Asker and Dr Tomoko Aizawa for helpful discussion and Shoichi Amano for his assistance with electron microscopic observations. This study was supported by the High-tech Research Center Program of the Ministry of Education, Culture, Sports, Science and Technology, Japan, and the New Energy and Industrial Technology Development Organization (NEDO) of Japan.

\section{References}

Chan, M., Himes, R. H. \& Akagi, J. M. (1971). Fatty acid composition of thermophilic, mesophilic, and psychrophilic clostridia. J Bacteriol 106, 876-881.

Collins, M. D., Lawson, P. A., Willems, A., Cordoba, J. J., FernandezGarayzabal, J., Garcia, P., Cai, J., Hippe, H. \& Farrow, J. A. E. (1994). The phylogeny of the genus Clostridium: proposal of five new genera and eleven new species combinations. Int J Syst Bacteriol 44, 812-826. 
Felsenstein, J. (1985). Confidence limits on phylogenies: an approach using the bootstrap. Evolution 39, 783-791.

Fitch, W. M. (1971). Toward defining the course of evolution: minimum change for a specific tree topology. Syst Zool 20, 406-416.

Galtier, N., Gouy, M. \& Gautier, C. (1996). SEAVIEW and PHYLO_WIN: two graphic tools for sequence alignment and molecular phylogeny. Comput Appl Biosci 12, 543-548.

Holdeman, L. V., Cato, E. P. \& Moore, W. E. C. (1977). Anaerobe Laboratory Manual, 4th edn. Blacksburg, VA: Anaerobe Laboratory, Virginia Polytechnic Institute and State University.

Jukes, T. H. \& Cantor, C. R. (1969). Evolution of protein molecules. In Mammalian Protein Metabolism, vol. 3, pp. 21-132. Edited by H. N. Munro. New York: Academic Press.

Kaneda, T. (1991). Iso- and anteiso-fatty acids in bacteria: biosynthesis, function, and taxonomic significance. Microbiol Rev 55, 288-302.

Kato, S., Haruta, S., Cui, Z. J., Ishii, M., Yokota, A. \& Igarashi, Y. (2004). Clostridium straminisolvens sp nov., a moderately thermophilic, aerotolerant and cellulolytic bacterium isolated from a cellulose-degrading bacterial community. Int J Syst Evol Microbiol 54, 2043-2047.

Kumar, S., Tamura, K. \& Nei, M. (2004). MEGA3: integrated software for molecular evolutionary genetics analysis and sequence alignment. Brief Bioinform 5, 150-163.

Le Ruyet, P., Dubourguier, H. C., Albagnac, G. \& Prensier, G. (1985). Characterization of Clostridium thermolacticum sp. nov., a hydrolytic thermophilic anaerobe producing high amounts of lactate. Syst Appl Microbiol 6, 196-202.

Madden, R. H. (1983). Isolation and characterization of Clostridium stercorarium sp. nov., cellulolytic thermophile. Int J Syst Bacteriol 33, 837-840.

Marmur, J. (1961). A procedure for the isolation of deoxyribonucleic acid from microorganisms. J Mol Biol 3, 208-218.

McBee, R. H. (1954). The characteristics of Clostridium thermocellum. J Bacteriol 67, 505-506.

Mesbah, M. \& Whitman, W. B. (1989). Measurement of deoxyguanosine/thymidine ratios in complex mixtures by high-performance liquid chromatography for determination of the mole percentage guanine + cytosine of DNA. J Chromatogr 479, 297-306.
Ng, T. K., Weimer, T. K. \& Zeikus, J. G. (1977). Cellulolytic and physiological properties of Clostridium thermocellum. Arch Microbiol 114, 1-7.

Saitou, N. \& Nei, M. (1987). The neighbor-joining method: a new method for reconstructing phylogenetic trees. Mol Biol Evol 4, 406425.

Shiratori, H., Ikeno, H., Ayame, S., Kataoka, N., Miya, A., Hosono, K., Beppu, T. \& Ueda, K. (2006). Isolation and characterization of a new Clostridium sp. that performs effective cellulosic waste digestion in a thermophilic methanogenic bioreactor. Appl Environ Microbiol 72, 3702-3709.

Stackebrandt, E. \& Goebel, B. M. (1994). Taxonomic note: a place for DNA-DNA reassociation and $16 \mathrm{~S}$ rRNA sequence analysis in the present species definition in bacteriology. Int J Syst Bacteriol 44, 846849.

Thompson, J. D., Higgins, D. G. \& Gibson, T. J. (1994). Clustal W: improving the sensitivity of progressive multiple sequence alignment through sequence weighting, position-specific gap penalties and weight matrix choice. Nucleic Acids Res 22, 4673-4680.

Toda, Y., Saiki, T., Uozumi, T. \& Beppu, T. (1988). Isolation and characterization of a protease-producing, thermophilic, anaerobic bacterium, Thermobacteroides leptospartum sp. nov. Agric Biol Chem 52, 1339-1344.

Wang, X., Hoefel, D., Saint, C. P., Monis, P. T. \& Jin, B. (2007). The isolation and microbial community analysis of hydrogen producing bacteria from activated sludge. J Appl Microbiol 103, 1415-1423.

Wayne, L. G., Brenner, D. J., Colwell, R. R., Grimont, P. A. D., Kandler, O., Krichevsky, M. I., Moore, L. H., Moore, W. E. C., Murray, R. G. E. \& other authors (1987). International Committee on Systematic Bacteriology. Report of the ad hoc committee on reconciliation of approaches to bacterial systematics. Int J Syst Bacteriol 37, 463-464.

Wiegel, J. (1980). Formation of ethanol by bacteria. A pledge for the use of extreme thermophilic anaerobic bacteria in industrial ethanol fermentation processes. Cell Mol Life Sci 36, 1434-1446.

Wiegel, J., Tanner, R. \& Rainey, F. A. (2006). An introduction to the family Clostridiaceae. In The Prokaryotes. A Handbook on the Biology of Bacteria, 3rd edn, vol. 4, pp. 654-678. Edited by M. Dworkin, S. Falkow, E. Rosenberg, K. H. Schleifer \& E. Stackebrandt. New York: Springer. 